\title{
Article
}

\section{An integrative review exploring decision- making factors influencing mental health nurses in the use of restraint}

\author{
Riahi, Sanaz, Thomson, Gillian and Duxbury, Joy
}

Available at http://clok.uclan.ac.uk/13605/

Riahi, Sanaz, Thomson, Gillian ORCID: 0000-0003-3392-8182 and Duxbury, Joy ORCID: 0000-0002-1772-6874 (2016) An integrative review exploring decision-making factors influencing mental health nurses in the use of restraint. Journal of Psychiatric and Mental Health Nursing, 23 (2). pp. 116 128. ISSN 1351-0126

It is advisable to refer to the publisher's version if you intend to cite from the work. http://dx.doi.org/10.1111/jpm.12285

For more information about UCLan's research in this area go to http://www.uclan.ac.uk/researchgroups/ and search for <name of research Group>.

For information about Research generally at UCLan please go to http://www.uclan.ac.uk/research/

All outputs in CLoK are protected by Intellectual Property Rights law, including Copyright law. Copyright, IPR and Moral Rights for the works on this site are retained by the individual authors and/or other copyright owners. Terms and conditions for use of this material are defined in the policies page.

\section{CLoK}

Central Lancashire online Knowledge www.clok.uclan.ac.uk

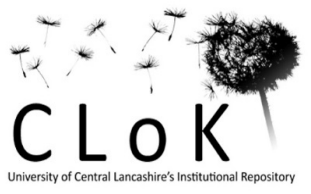




\begin{abstract}
Introduction: While mechanical and manual restraint as an institutional method of control within mental health settings may be perceived to seem necessary at times, there is emergent literature highlighting the potential counter-therapeutic impact of this practice for patients as well as staff. Nurses are the professional group who are most likely to use mechanical and manual restraint methods within mental health settings. In-depth insights to understand what factors influence nurses' decisionmaking related to restraint use are therefore warranted. Aim: To explore what influences mental health nurses' decision-making in the use of restraint.
\end{abstract}

Method: An integrative review using Cooper's framework was undertaken. Results: Eight emerging themes were identified: 'safety for all', 'restraint as a necessary intervention', 'restraint as a last resort', 'role conflict', 'maintaining control', 'staff composition', 'knowledge and perception of patient behaviours', and 'psychological impact'. These themes highlight how mental health nurses' decision-making is influenced by ethical and safety responsibilities, as well as, interpersonal and staff related factors. Conclusion: Research to further understand the experience and actualization of 'last resort' in the use of restraint and to provide strategies to prevent restraint use in mental health settings are needed.

Key Words: Containment, Decision-Making, Integrative Review, Mental Health, Psychiatric Nursing, Restraint 


\section{Summary Statement}

\section{What is known on the subject?}

- There is emerging evidence highlighting the counter therapeutic impact of the use of restraint and promoting the minimization of this practice in mental health care.

- Mental health nurses are often the professional group using restraint and understanding factors influencing their decision-making becomes critical.

- To date, there are no other published papers that have undertaken a similar broad search to review this topic.

\section{What this paper adds to existing knowledge?}

- Eight emerging themes are identified as factors influencing mental health nurses decisions-making in the use of restraint.

- The themes are: 'safety for all', 'restraint as a necessary intervention', 'restraint as a last resort', 'role conflict', 'maintaining control', 'staff composition', 'knowledge and perception of patient behaviours', and 'psychological impact'.

- 'Last resort' appears to be the mantra of acceptable restraint use, although, to date, there are no studies that specifically consider what this concept actually is.

\section{What are the implications for practice?}

- These findings should be considered in the evaluation of the use of restraint in mental health settings and appropriate strategies placed to support shifting towards restraint minimization. 
- As the concept of 'last resort' is mentioned in many policies and guidelines internationally with no published understanding of what this means, research should prioritize this as a critical next step in restraint minimization efforts. 


\section{INTRODUCTION}

Control and containment measures, such as restraint, are often used as first line interventions within healthcare settings (Cowin et al., 2003; Foster et al., 2007; Kynoch et al., 2011) and frequently used in the treatment and management of disruptive and aggressive behaviours (Sailas \& Fenton, 2012). The term 'restraint', although lacking standardization in definition, has been most recently defined by Sailas and Fenton (2012) in a Cochrane systematic review on 'seclusion and restraint for people with serious mental illness' as: "[it] involves measures designed to confine a patient's bodily movements" (Sailas \& Fenton, 2009, P.2). The focus of this paper is on mechanical and manual restraint, whereby it involves the use of "straps, belts or other equipment to restrict movement" (Stewart et al., 2009, p. 2)or by "any occasion on which staff physically hold the patient, preventing movement, typically in order to prevent imminent harm to others or self, or to give treatment, or to initiate other methods of containment" (Bowers et al., 2012, p. 31; CIHI, 2011). The term 'restraint' in this paper will refer to mechanical and manual restraint.

\section{Background}

While restraint as an institutional method of control, may be perceived as warranted at times, there is growing literature indicating the potential countertherapeutic (non-beneficial) effects of this practice (Borckardt et al., 2011). As a result, in more recent years, there has been a mandate through various legislations, guidelines and papers in countries, such as Canada, USA and UK, for organizations to shift towards the minimization of restraint, whereby its use is only as a 'last resort' 
when all other alternative interventions have been exhausted (American Psychiatric Nurses Association, 2014a, 2014b; College of Nurses of Ontario, 2009; Department of Health, 2014; MIND for better mental health, 2013; National Institute for Health and Care Excellence, 2015; National Offenders Management Services, 2013; Registered Nurses Association of Ontario, 2012; Riahi et al., 2014; Royal College of Nursing, 2008). This movement supports health care organizations in placing greater emphasis and investment on proactive, preventative approaches, such as sensory modulation, staff mix review and training and education, in the prevention and management of violence and aggression.

A Cochrane review in 2009 was undertaken to assess the effectiveness of the use of restraint and seclusion compared to alternatives, such as educational and behavioural strategies, policy changes, and medication, for those with serious mental illnesses. The review concluded that "no controlled studies exist that evaluate the value of seclusion or restraint in those with serious mental illness" (Sailas \& Fenton, 2009, p.2). Other reviews report similar findings (Muralidharan \& Fenton, 2012; Nelstrop et al., 2006; Sailas \& Fenton, 2012). Furthermore, evidence has linked the use of restraint to a number of adverse outcomes, such as further exacerbation of aggression, injury to staff or patients, increased organizational costs, re-traumatization, and rupture of the therapeutic alliances amongst staff and patients (Ashcraft \& Anthony, 2008; Bonner et al., 2002; Fisher, 2003; Foster et al., 2007; Mildred, 2002; Moran et al., 2009; Sequeira \& Halstead, 2004). Some of the physical injuries identified in studies include coma, abrasions, bruises, and fractured bones, as well as, deaths due to asphyxiation, cardiac arrest, strangulation, drug 
overdose or interaction, blunt trauma, choking and neglect secondary to the use of restraint and seclusion (Mildred, 2002). Sailas and Fenton (2009) argue that continuing the use of restraint must be questioned from within well-designed and reported randomized trials that are generalizable to routine practice_(Duxbury, 2015).

Studies exploring the use of restraint have identified that the most common circumstances where restraint is utilised are in response to violent patient behaviour, abscondment, staff denial of a request, patient agitation, refusal of medication, self-harm, verbal aggression and property damage (Bowers et al., 2012; Gudjonsson et al., 2004; Ryan \& Bowers, 2006; Southcott \& Howard, 2007). Other qualitative studies illustrate that nurses view restraint as a necessary intervention which is distressing, and view the organizational culture, staff experience and composition, conflict, ethical considerations, and patient characteristics as contributing factors (Bigwood \& Crowe, 2008; Bowers et al., 2012; Happell \& Harrow, 2010; Sequeira \& Halstead, 2004).

Though there is a paucity of literature that explores patients' perspectives and experiences in the use of restraint, those that do exist reveal that patients do not view this practice as needed or effective_(Riahi et al., 2014). Soininen et al. (2013) for example, explored patients' perceptions of their hospital treatment following seclusion or restraint and found that patients were unsatisfied with their overall treatment, felt that seclusion and restraint were 'hardly' necessary, and that perceptions varied by age. The older the patient, the less they perceived seclusion 
and restraint to be necessary. Patients' believed that their opinions were not included in treatment planning and patients' perceptions did not differ when they were mechanically restrained or secluded (Soininen et al., 2013). The Psychiatric Patient Advocate Office (PPAO) reviewed seclusion and restraint practices in Ontario (Canada) psychiatric hospitals and found that more than $50 \%$ of the patients considered that they had not posed a threat to themselves or others at the time they were restrained or secluded (Riahi et al., 2014). Additionally, once in seclusion or restraint, almost 50\% said they did not know what was required of them in order to be released (PPAO, 2000). Other studies indicate that when patients are restrained this can lead to feelings of anger, fear, panic, and a sense of feeling dismissed (Bonner et al., 2002; Bowers et al., 2012; Sequeira \& Halstead, 2004).

The term 'last resort' is cited in policy and research to promote the use of restraint only when all other less intrusive alternatives have been exhausted and deemed ineffective (Bonner et al., 2002; Moran et al., 2009). However, Deveau and McDonnell (2009) argue that the "reliance upon the 'last resort' principle has the major drawback that it is an easily voiced rhetorical device and very difficult to observe or challenge" (p.175). There is growing evidence internationally indicating that the use of restraint is counter-therapeutic, coercive, punishing, traumatic and unnecessary (Curran, 2007; Soininen et al., 2013). Restraint is also considered to be over-used under false assumptions that it is an effective means to manage violence and aggression and can protect and assure the safety of patients and staff (Cutcliffe \& Santos, 2012). As mental health nurses are generally the ones who implement 
restraint in mental health settings, further research to explore how 'last resort' is enacted within their practice is therefore warranted.

The original aim of this integrative review was to explore mental health nurses' decision-making processes that influence when and how mechanical and manual restraint should be used as a 'last resort'. As an initial scoping review was unable to locate any primary research that explicitly focused on this phenomenon, a more inclusive approach to explore factors that influenced nurses' decision-making in the use of restraint was adopted. It was considered that these in-depth insights would help to illuminate the range of situational, environmental and personal factors that impact on decision-making and would help inform future research on the concept of restraint as a 'last resort' within practice.

\section{Aim}

To explore what influences mental health nurses' decision-making in the use of mechanical and manual restraint.

\section{Method}

An integrative review of the literature was undertaken, using Cooper's (1989) framework. This narrative descriptive method enables the inclusion of diverse methodologies allowing for a greater depth and breadth of the research topic. Integrative review summarizes previous empirical or theoretical literature to provide greater insight in understanding a specific phenomenon (Whittemore \& Knafl, 2005). Additionally, "well-done integrative reviews present the state of science, 
contribute to theory development, and have direct applicability to practice and policy" (Whittemore \& Knafl, 2005, p. 546). Cooper's framework includes five stages: 1) problem identification stage; 2) literature search stage; 3) data evaluation; 4) data analysis stage; and 5) presentation (Whittemore \& Knafl, 2005).

\section{Problem Identification Stage}

Currently there is a gap in the body of literature related to the various factors influencing mental health nurses decisions in using restraint as a 'last resort'. In addition, there is very limited published literature that explores mental health nurses' overall decision-making related to restraint use_(Goethals et al., 2012; Laiho et al., 2013). A greater in-depth understanding of the factors influencing decisionmaking may aid in undertaking future research to explore 'last resort', to enhance knowledge and influence overall strategies at both the clinician and organizational levels, as well as help to advance restraint minimization.

\section{Literature Search Stage}

The databases searched were Medline, Cochrane, CINAHL (Ebsco), Psychinfo, and EMBASE. The PICO (population/intervention/context/outcome) format was used to translate the research question into an effective search strategy. The key terms searched are included in Table 1. The inclusion and exclusion criteria for identified literature in the review are detailed in Table 2. Studies published up to March 2014 were included in this review. Due to the paucity of literature it was

\section{decided among the authors that studies which explicitly included manual and or}


mechanical and seclusion as interventions would be included in this review. As per

the exclusion criteria, studies that only explored seclusion were not included. The rationale for this was to ensure inclusivity of the limited yet important studies

exploring restraint use among mental health nurses. Restraint and seclusion have

commonly been included in a number of key studies and to exclude them would be a

mistake. For example, experts in the field who have developed approaches such as

the Six Core Strategies in the minimization of restraint use have tackled restraint

and seclusion together (Huckshorn, 2004; LeBel et al., 2014; Putkonen et al., 2013),

In addition to the database searches, Bates's (1989) 'berry-picking' approach was adopted. This approach was used in the initial steps of scoping the research question and defining the concepts of 'last resort' and 'restraint', as well as, during the data evaluation stage. The berry-picking strategies included in this review were: 1) footnote chasing; 2) citation searching; 3 ) journal run; 4) area scanning; 5) subject searches in bibliographies and abstracting and indexing; and 6) author searching (Bates, 1989). A total of 22 articles in addition to the database search were identified and reviewed as a result of these approaches.

\section{Data Evaluation}

The next step in Cooper's (1989) integrative review framework is data evaluation. The Critical Appraisal Skills Program (CASP) tools were utilized to appraise the articles Modifications were made to the CASP tools to appraise quantitative and mixed method studies as these broad categories are not available in the existing CASP suite. Each article was reviewed and appraised by two 
reviewers and graded using the system described in Table 3 (Walsh \& Downe, 2006). Key domains appraised included: appropriate research design, sampling,

\section{data collection, reflexivity, ethics, data analysis, findings, and value of research as}

per the CASP criteria. The grading was then compared for significant discrepancies, of which there were none. Due to the small sample size of articles, only those receiving a grade $\mathrm{D}$, indicating significant flaws in the study likely to affect its validity, reliability and generalizability, were removed_i.e. lack of methodological detail). The decision to reject papers was also made if they did not add to the body of knowledge relative to the findings from others deemed to be of high methodological quality. This led to three studies being removed, leaving 16 articles as the final number to be included in the integrative review.

\section{Data Analysis}

One of the least developed aspects of the integrative review process is the strategy for data analysis. A constant comparison method is a recommended method, which is an overarching approach in the development of the results in this integrative review (Whittemore \& Knafl, 2005). This method was deployed and involved the analysis of studies where the data were extracted into systematic categories, identifying distinct patterns, themes and relationships within and across the studies. Overall, eight key themes were identified in relation to factors influencing mental health nurses' decision-making in the use of restraint. 
The flow diagram in Figure 1 summarizes the literature search, data evaluation and analysis stages. Table 4 provides a summary of the studies and the key themes identified within each individual paper.

\section{RESULTS}

The results represent the findings from the 'data analysis' and 'presentation' stages of the integrative review process where key insights are identified, reported and visually represented. A total of 16 articles were included in the review, eight qualitative research articles, seven quantitative research articles and one mixed method research article. Key areas of focus for the articles were nurses' decisionmaking for the use of restraint $(n=3)$, nurses' perceived experience of restraint $(n=8)$, nurses' attitudes towards restraint $(n=4)$, and relationships of show of force ["a number of staff are assembled within view of the patient, with the implicit or explicit threat that the patient will be manually restrained or forced to undergo treatment, unless they comply voluntarily"] (Bowers et al., 2012, p. 31) and manual restraint compared to other factors $(n=1)$. The articles were published in the United Kingdom ( $n=5)$, United States $(n=5)$, Finland $(n=1)$, New Zealand $(n=1)$, Canada $(n=1)$, Ireland $(n=1)$, Greece $(n=1)$ and Israel $(n=1)$.

Overall, eight themes were identified. While an array of factors have been identified to influence mental health nurses' decision-making in the use of restraint, it is also important to identify their inter-relational nature. For example, the themes of 'safety for all' and 'restraint as a necessary intervention' are significantly interrelated. Nurses perceived restraint as a necessary intervention primarily to 
maintain safety for both patients and staff. Similarly, maintaining control of the situation was highly influenced by safety for all, which again was associated with viewing restraint as a necessary intervention. The eight emergent themes are 'safety for all', 'restraint as a necessary intervention', 'restraint as a last resort', 'role conflict', 'maintaining control', 'staff composition', 'nurses' knowledge and perception of the patient', and 'psychological impact'. A visual representation of the data has been developed to display findings in Figure 2 .

\section{Safety for All}

The concept of safety was a prominent theme to emerge (Bigwood \& Crowe, 2008; Lemonidou et al., 2002; Terpstra, 2001). Terpstra et al. (2001) for example, in exploring staff's attitudes and opinions of seclusion and restraint, found that $40 \%$ of respondents felt restraint was a more effective approach in helping a patient 'calm down'. Their reason for choosing this method was that 'restraint reduced physical injury to all involved' (Terpstra, 2001). Additionally, this study reported that one of the most frequent reasons that nurses used restraint was due to a perception that greater safety was achieved both for staff and other patients (Terpstra, 2001). Similarly, Lemonidou et al. (2002) when exploring nurses' attitudes towards seclusion and restraint reported that $70.5 \%$ of the nurses used restraint most often for the safety of patients and others. Nurses in one study reported feeling scared at a personal level because of the risk of actual harm, where the fear of this impending danger activated some 'self-preservative' responses (Bigwood \& Crowe, 2008). 


\section{Restraint as a Necessary Intervention}

While very closely related to the theme of 'safety' a further key issue highlighted nurses' perceptions of restraint as a necessary intervention. In a number of studies this was inherently linked to nurses' professional responsibility and accountability to provide a safe environment for all concerned (Bigwood \& Crowe, 2008; McCain \& Kornegay, 2005; Perkins et al., 2012). Similarly, Bigwood and Crowe (2008) reported restraint to be 'part of the job' to prevent harm or injury to patients or others and considered this to be "an integral, essential, and unavoidable part of acute mental health nursing practice" (Bigwood \& Crowe, 2008, p. 218). Similarly, in exploring the attitudes of staff towards restraint and factors influencing decision-making, Perkins et al. (2012) reported that although the use of restraint as a last resort was recognized, it was also viewed as a 'necessary evil'. One participant stated:

“You need it because it's for your safety and other people's safety. Because, you just need it there because it you didn't have it, people could get hurt. I mean I know it's not the nicest thing, and it is uncomfortable, but you have got to look at it, at the safety aspects of what could happen if we don't use restraints" (Perkins et al., 2012, p. 46).

\section{Restraint as a Last Resort}

While there is some evidence reporting nurses' views for restraint to be a necessary intervention, studies also identified how nurses were strongly committed 
to use restraint only as a last resort and displayed dislike in its use (Bonner et al., 2002; Holzworth \& Wills, 1999; Lindsey, 2009). Similarly, within a number of studies nurses expressed adopting a least restrictive approach where other alternatives such as, creating a calmer environment, therapeutic communication with the patient and administration of medications, were attempted prior to the use of restraint (Holzworth \& Wills, 1999; Lindsey, 2009; Marangos-Frost \& Wells, 2000; McCain \& Kornegay, 2005; Moran et al., 2009).

\section{Role Conflict}

An emerging theme in the literature was the interface between ethics and safety. Several studies illustrated how nurses experienced a conflict in their role, while endeavouring to preserve safety, and feeling the need to participate in an intervention that they disliked while attempting to use restraint as a last resort. Bigwood and Crowe (2008) and Marangos-Frost and Wells (2000) frame this as the 'conflicted nurse' where ethical and safety values need to be balanced. Kontio et al. (2010) identified nurses' decision-making about restraint application as an ethical dilemma, in terms of nurses' needing to consider patients versus others' best interests. Similarly, Bonner et al. (2002) explored the lived subjective experience of restraint from nurses where 'ethical issues' were an emerging theme. Moylan and Cullinan (2011) reported nurses' beliefs that aggressive behaviours by patients were an expected part of the mental health nurses' role and that nurses felt pressure to avoid restraint use. 


\section{Maintaining Control}

Nurses being in control and taking control of the situation was another common theme. Perkins et al. (2012) study for example reported 'taking control' to be a central feature in nurses rationalizations of the use of restraint and which included two conceptualizations: 1) 'restraint as a technique to directly suppress aggressive and violent behaviour'; 2) 'restraint as a management strategy to maintain order and stability within the organizational setting'. The study revealed that the participants considered physical intervention as a 'battleground for control' among staff and patients (Perkins et al., 2012). One nurse articulates this experience by stating:

"The minute you lay hands on, the incident that originally got you to that point, is lost, it then becomes a situation of well you know, get off me, I will calm down when you get off me, and then the retort from the staff side is well no, when you have calmed down, and the service user then says well I will calm down when you get off me, and it then becomes a stalemate... a service-user, might calm down quicker if the restraint wasn't so long, instead of being forced, as it were, into submission, sort of like we will take hands-off when we feel you have calmed down" (Perkins et al., 2012, p. 46).

Lee et al. (2003) explored nurses' views relating to their last experience of implementing restraint and $96.3 \%$ of respondents perceived that there had been a positive outcome in their last incident. This positive perception was correlated with 
the perspective that the incident was controlled, regardless of the aftermath. Terpstra et al. (2001) found the most frequent reason provided by nurses for the use of restraint and seclusion was that the interventions were more likely to result in immediate control of violent behaviour. Similarly, 'behaviour control' was the second highest reason (23.2\%) nurses cited as needing to use restraint in Lemonidou et al.'s (2002) study. Bigwood and Crowe (2008) found that nurses upheld an expectation that maintaining control was integral to the job, with some considering this practice to be therapeutic:

"I view restraint as a necessary therapeutic tool. Yes it is unavoidable in certain circumstances. Definitely it is a therapeutic intervention that is necessary at that point of time of crisis, to either reinstate control, to create safe outcome, to impose a treatment plan, to keep everyone safe basically and to just reestablish control" (Bigwood \& Crowe, 2008, p. 219).

Lindsey's (2009) study reported a significant negative correlation between mental health nurses sense of empowerment and decision to restrain. Empowerment in this study entailed the following domains: opportunity, information, support, resources, formal power, and informal power (Lindsey, 2009). Respondents in Lee et al.'s (2003) study revealed negative staff attitudes when restraint were initiated, such as a 'bouncer mentality', 'deck them first' and a tendency to use restraint 'too quickly', all of which are aligned with a sense of maintaining control. 
Nurses' Knowledge and Perception of the Patient

Familiarity with the patient, in terms of knowing their behavioural patterns and triggers as well as knowledge of patient's past behaviour seemed to help inform nurses' expectations of an individual's behaviour and essentially influence their decision-making to restrain (Perkins et al., 2012). Lindsey (2009) for example, found nurses' perceptions of the patient's familiarity with the unit rules and norms influenced their decision to restrain. Nurses were therefore less inclined to use restraint if the patient was 'new' to the unit and unfamiliar with the rules. Factors contributing to nurses' knowledge and perception of the patients which influenced whether restraint methods were applied included: injury, danger or harm to self or others (Gelkopf et al., 2009; Holzworth \& Wills, 1999; Lee et al., 2003; Lindsey, 2009; Terpstra, 2001), agitation, destruction of property (Holzworth \& Wills, 1999; Lee et al., 2003), stress, anger, aggressiveness (Lemonidou et al., 2002), age, and diagnosis (Lindsey, 2009). These factors were viewed as information for the nurses about the patient, which influenced nurses' perception of the patient and inadvertently shaped decision-making related to restraint use.

\section{Staff Composition}

Staff composition was another emerging theme. In Terpstra et al.'s study (2001) for example, 51\% $(n=33)$ of the nurse participants specified that staff mix on their ward swayed their decision-making related to restraining a patient. The study did not define the term staff mix, although commonly staff mix refers to the blend of 
various categories of health-care personnel employed for providing direct patient care (McGillis Hall, 2005). This study also reported that $48 \%(n=31)$ of respondents considered that the number of staff present was influential in their decision to restrain, whereby a fewer number of staff contributed to a sense of fear in approaching difficult patient-related situations and further influenced the likelihood to use restraint (Terpstra, 2001). Evening shifts were reported to increase the frequency of restraint use by $51 \%$ in one study (Lemonidou et al., 2002). Lemonidou et al. also found that 'staffing' was the most important environmental factor (56.3\%) impacting nurses' decision-making in the use of restraint. Similar results were reported by Lee et al. (2003) who identified understaffing, regular use of agency staff, and inexperienced staff in the management of violence as important organizational factors impacting upon decision-making. Interestingly, Bowers et al. (2012) reported the 'better' and 'more richly-staffed' the wards were, the higher the use of coercive measures, including restraint, were used.

There are some inconsistencies within the literature regarding the impact of professional experience and the decision to restrain by mental health nurses. Lindsey (2009) reported nurses with greater experience in both nursing and psychiatric nursing were more likely to use restraint as their initial intervention. Similarly, another study reported a positive correlation among the length of time nurses worked on a unit and the mean number of restraint episodes they were involved in (Terpstra, 2001). However, Holzworth and Wills (1999) found the most restrictive type of interventions were made by nurses with the least amount of experience professionally. They made nearly three times as many recommendations 
in comparison to those with greater professional experience. Similarly, one study reported that $49.5 \%$ of nurses considered that the most important environmental factor to influence the use of restraint was inexperienced nursing staff (Gelkopf et al., 2009).

Gender was another staff composition factor identified in the literature. Gelkopf et al. (2009) found more male nurses in comparison to female nurses, considered the use of restraint if patients refused medication, kept others from sleeping, 'bothered' other patients, fought with other patients, and continuously banged on the nurses' windows. Bowers et al. (2012) explored staff variables in using restraint and found an increase in use when security guards were present as part of the staff composition.

\section{Psychological Impact}

The studies included did not directly address the psychological effects of the aftermath of restraint use on future decision-making. However, the psychological impact of the after-effects of restraint use among nurses was a key theme in a number of the selected studies (Bonner et al., 2002; Moran et al., 2009; Sequeira \& Halstead, 2004). 'Re-traumatization' of violent incidents for example was reported by nurses in Bonner et al.'s (2002) study, where one nurse stated, "even smaller incidents like this can trigger thoughts of previous incidents" (p. 471). One study reported that nurses who had a history of being injured in the past would influence their decision to restrain a patient at a later time in the progression of aggression 
(Moylan \& Cullinan, 2011). Sequeira and Halstead (2004) reviewed the psychological responses of nurses to restraint and reported a number of findings. Anxiety was the most prevalent emotion nurses experienced when using restraint, with a noted reduction in anxiety when restraint usage was familiar to the nurse (Sequeira \& Halstead, 2004).

\section{DISCUSSION}

Overall, the emerging themes from this review suggest a paradoxical situation for mental health nurses, where they use restraint to maintain safety for all (Bigwood \& Crowe, 2008; Lemonidou et al., 2002; Terpstra, 2001), with safety viewed as an integral part of their role (Bigwood \& Crowe, 2008; McCain \& Kornegay, 2005; Perkins et al., 2012), despite the fact that there is existing evidence that demonstrates that restraint poses safety risks for both patients and staff (Ashcraft \& Anthony, 2008; Fish \& Culshaw, 2005; Foster et al., 2007; Mildred, 2002; Sequeira \& Halstead, 2004; Soininen et al., 2013; Strout, 2010).

A literature review to explore nurses' decision-making in the use of restraint in mental health settings was undertaken by Laiho and colleagues (2013). Key findings identified a number of domains, which impact on nurses' decision-making in the use of restraint: 'patient-related cues', 'personnel-related cues', 'previous experience of the use of seclusion or restraint', and 'organizational-related cues' (Laiho et al, 2013). While the current study confirms the findings from this previous review, two additional, previously unreported issues emerged in relation to 
'restraint as a last resort' and 'staff composition'. Additionally, the current study undertook a broader search with the use of PICO search strategy.

The staff composition theme highlights inconsistences in terms of how staffing numbers (high or low) and level of experience (inexperienced or well experienced) can influence restraint use, as well as how restraint use is influenced by gender issues and the presence of security personnel. These findings therefore emphasise the need for further consideration of staff related factors in a mental health environment.

The concept of 'last resort' is mentioned in many policies and guidelines (American Psychiatric Nurses Association, 2014a, 2014b; College of Nurses of Ontario, 2009; Department of Health, 2014; MIND for better mental health, 2013; National Institute for Health and Care Excellence, 2015; National Offenders Management Services, 2013; Registered Nurses Association of Ontario, 2012; Royal College of Nursing, 2008) around the world and can be viewed as a key driver for nurses in making decisions related to the application of restraint. As this review has identified that no existing studies focus on, nor clearly consider what 'last resort' actually means, further exploration into how this concept is perceived and enacted upon in practice appears critical. This could potentially provide insights into strategies that support and prevent the use of restraint in mental health settings.

A key strength of an integrative review is the combination of diverse methodologies, which provides an opportunity for an in-depth review of the evidence, providing a depth and breadth of the evidence without over-emphasizing and over-valuing hierarchies of evidence. However, this may also be viewed as a 
limitation as the combining of diverse methodologies may be argued to contribute to a lack of rigor, inaccuracies and bias. While only published research studies were included, a broad and inclusive search strategy was adopted to ensure that all key studies were included. All the authors also undertook the analysis and identification of themes until consensual validation had been obtained. A further strength of the review is the similarities of findings with other reviews, demonstrating a robust methodology, as well as, validity to the key influences on mental health nurses decision-making in restraint use. Furthermore, as new and previously unreported issues were identified, this review provided new and unique contributions to knowledge in this area of practice. A limitation of this review concerns the generalizability of the findings to institutions in countries where decisions related to restraints tend to involve other healthcare professionals. Furthermore, although many countries are moving towards restraint minimization, practices and definitions vary. This therefore creates difficulties in drawing comparisons about $\underline{\text { restraint use across different study contexts. }}$

The topic of restraint use in mental health is controversial. There are some who question whether restraint could ever be therapeutic (Huckshorn, 2004; Paterson \& Duxbury, 2007), while others believe restraint is necessary, but only in extreme situations (Fisher, 1994; Mohr et al., 1998). In addition, while research from clinicians' perspectives report how restraint maintains safety (Bigwood \& Crowe, 2008; Lemonidou et al., 2002; Stubbs et al., 2009; Terpstra, 2001), there is evidence that reductions in restraint can increase safety for staff (Goetz, 2012; LeBel et al., 2014; Lebel \& Goldstein, 2005). As restraint use has negative physical and 
psychological consequences (Fish \& Culshaw, 2005; Sequeira \& Halstead, 2004;

Soininen et al., 2013; Strout, 2010), there is a need to further understand the intricacies involved in decision-making to use restraint as a 'last resort' in mental health settings.

\section{IMPLICATIONS FOR PRACTICE}

Mental health nurses' decision-making is influenced by interrelated issues of ethical and safety responsibilities, as well as, interpersonal and staff related factors. Although nurses reported restraint as a necessary intervention, they also reported their dislike of this intervention and at times viewed it as a last resort, leaving them conflicted in their role. Additionally, it draws attention to the importance of understanding and taking into consideration these situational, environmental and personnel related factors that influence restraint use by hospital leaders in shifting towards restraint minimization practices.

'Last resort' appears to be the mantra of acceptable restraint use. However to date, there are no studies that specifically consider what this concept actually is. Further studies are needed to understand how 'last resort' is experienced and actualized by mental health nurses in restraint use. This would enable greater understanding of how restraint minimisation can be achieved and the supports required for mental health nurses. 


\section{REFERENCES}

American Psychiatric Nurses Association, A. P. N. A. (2014a). APNA Position Statment on the Use of Seclusion and Restraint. USA.

American Psychiatric Nurses Association, A. P. N. A. (2014b). Seclusion and Restraint Standards of Practice. USA.

Ashcraft, L., \& Anthony, W. (2008). Eliminating seclusion and restraint in recoveryoriented crisis services. Psychiatric Services, 59(10), 1198-1202.

Bigwood, S., \& Crowe, M. (2008). 'It's part of the job, but it spoils the job': A phenomenological study of physical restraint. International Journal of Mental Health Nursing, 17(3), 215-222. doi: 10.1111/j.1447-0349.2008.00526.x

Bonner, G., Lowe, T., Rawcliffe, D., \& Wellman, N. (2002). Trauma for all: A pilot study of the subjective experience of physical restraint for mental health inpatients and staff in the UK. Journal of Psychiatric and Mental Health Nursing, 9(4), 465-473. doi: 10.1046/j.1365-2850.2002.00504.x

Borckardt, J., Madan, A., Grubaugh, A., Kmett Danielson, C., Pelic, C., Hardesty, S., . . . Frueh, B. (2011). Systematic investigation of initiatives to reduce seclusion and restraint in a state psychiatric hospital. Psychiatric Services, 62(5), 477483.

Bowers, L., Van Der Merwe, M., Paterson, B., \& Stewart, D. (2012). Manual restraint and shows of force: The City-128 study. International Journal of Mental Health Nursing, 21(1), 30-40. doi: 10.1111/j.1447-0349.2011.00756.x

CIHI. (2011). Restraint Use and Other Control Interventions for Mental Health Inpatients in Ontario. Ontario, Canada: Canadian Institute for Health Information.

College of Nurses of Ontario, C. o. N. o. O. (2009). Restraints Practice Standards. Ontario, Canada.

Cooper, H. M. (1989). Integrating Research: A Guide for Literature Reviews (Second ed.). California, USA: SAGE Publications.

Cowin, L., Davies, R., Estall, G., Berlin, T., Fitzgerald, M., \& Hoot, S. (2003). Deescalating aggression and violence in the mental health setting. International Journal of Mental Health Nursing, 12, 64-73.

Curran, S. S. (2007). Staff resistance to restraint reduction: Identifying and overcoming barriers. Journal of Psychosocial Nursing and Mental Health Services, 45(5), 45-50.

Cutcliffe, J., \& Santos, J. (2012). Suicide and Self-Harm: an evidence-informed approach. UK: Quay Books. 
Department of Health, D. o. H. (2014). Positive and Proactive Care: Reducing the Need for Restrictive Interventions. UK.

Deveau, R., \& McDonnell, A. (2009). As the last resort: reducing the use of restrictive physical interventions using organisational approaches. British Journal of Learning Disabilities, 37(3), 172-177. doi: 10.1111/j.1468-

3156.2008.00536.x

Duxbury, J. (2015). The Eileen Skellern Lecture 2014: physical restraint: in defence of the indefensible? Journal of Psychiatric and Mental Health Nursing, 22(2), 92-101.

Fish, R., \& Culshaw, E. (2005). The Last Resort? Staff and Client Perspectives on Physical Intervention. Journal of Intellectual Disabilities, 9(2), 93-107.

Fisher, J. (2003). Curtailing the use of restraint in psychiatric settings. Journal of Humanistic Psychology, 43(2), 69-95.

Fisher, W. A. (1994). Restraint and Seclusion: A Review of the Literature. The American Journal of Psychiatry, 151(11), 1584-1591.

Foster, C., Bowers, L., \& Nijman, H. (2007). Aggressive behavior on acute psychiatric wards: prevalence, severity and management. Journal of Advanced Nursing, 58(2), 140-149.

Gelkopf, M., Roffe, Z., Behrbalk, P., Melamed, Y., Werbloff, N., \& Bleich, A. (2009). Attitudes, opinions, behaviors, and emotions of the nursing staff toward patient restraint. Issues in Mental Health Nursing, 30(12), 758-763. doi: 10.3109/01612840903159777

Goethals, S., de Casterlé, B. D., \& Gastmans, C. (2012). Nurses' decision - making in cases of physical restraint: A synthesis of qualitative evidence. Journal of Advanced Nursing, 68(6), 1198-1210. doi: 10.1111/j.13652648.2011.05909.x

Goetz, S. B. T.-T., A. (2012). A Change in Culture: Violence Prevention in an Acute Behavioral Health Setting. Journal of the American Psychiatric Nurses Association, 18(2), 96-103.

Gudjonsson, G., Rabe-Hesketh, S., \& Szmukler, G. (2004). Management of psychiatric inpatient violence: Patient ethnicity and use of medication, restraint and seclusion. British Journal of Psychiatry, 184, 258-262.

Happell, B., \& Harrow, A. (2010). Nurses' attitudes to the use of seclusion: a review of the literature. International Journal of Mental Health Nursing, 19(3), 162168.

Holzworth, R. J., \& Wills, C. E. (1999). Nurses' Judgments Regarding Seclusion and Restraint of Psychiatric Patients: A Social Judgment Analysis. Research in Nursing \& Health, 22, 189-201.

Huckshorn, K. A. (2004). Reducing Seclusion and Restraint Use in Mental Health Settings: Core Strategies for Prevention. Journal of Psychosocial Nursing \& Mental Health Services, 42(9), 22-33.

Kontio, R., Valimaki, M., Putkonen, H., Kuosmanen, L., Scott, A., \& Joffe, G. (2010). Patient restrictions: Are there ethical alternatives to seclusion and restraint? Nursing Ethics, 17(1), 65-76. 
Kynoch, K., Wu, C., \& Chang, A. (2011). The effectiveness of interventions in the prevention and management of aggressive behaviours in patients admitted to an acute hospital setting: A systematic review. World Views on EvidenceBased Nursing, Second Quarter, 76-86.

Laiho, T., Kattainen, E., Åstedt - Kurki, P., Putkonen, H., Lindberg, N., \& Kylmä, J. (2013). Clinical decision making involved in secluding and restraining an adult psychiatric patient: An integrative literature review. Journal of Psychiatric and Mental Health Nursing, 20(9), 830-839.

LeBel, J., Duxbury, J. A., Putkonen, A., Sprague, T., Rae, C., \& Sharpe, J. (2014). Multinational Experiences in Reducing and Preventing the Use of Restraint and Seclusion. Journal of Psychosocial Nursing, 52(11), 22-29.

Lebel, J., \& Goldstein, R. (2005). The Economic Cost of Using Restraint and the Value Added by Restriant Reduction or Elimination. Psychiatric Services, 56(9), 1109-1114.

Lee, S., Gray, R., Gournay, K., Wright, S., Parr, A., \& Sayer, J. (2003). Views of nursing staff on the use of physical restraint. Journal of Psychiatric \& Mental Health Nursing, 10(4), 425-430. doi: 10.1046/j.1365-2850.2003.00625.x

Lemonidou, C., Priami, M., Merkouris, A., Kalafati, M., Tafas, C., \& Plati, C. (2002). Nurses' perceptions toward seclusion and use of restraints for psychiatric patients in Greece. The European Journal of Psychiatry, 16(2), 81-90.

Lindsey, P. L. (2009). Psychiatric nurses' decision to restrain: the association between empowerment and individual factors. Journal of Psychosocial Nursing \& Mental Health Services, 47(9), 41-49. doi: 10.3928/0279369520090730-02

Marangos-Frost, S., \& Wells, D. (2000). Psychiatric nurses' thoughts and feelings about restraint use: a decision dilemma. Journal of Advanced Nursing, 31(2), 362-369. doi: 10.1046/j.1365-2648.2000.01290.x

McCain, M., \& Kornegay, K. (2005). Behavioral health restraint: the experience and beliefs of seasoned psychiatric nurses. Journal for Nurses in Staff Development - JNSD, 21(5), 236-242.

McGillis Hall, L. (2005). Nursing Staffing. In L. McGillis Hall (Ed.), Quality Work Environments for Nurse and Patient Safety (pp. 9-37). Sudbury, MA: Jones and Bartlett.

Mildred, L. (2002). Seclusion and restraints: A failure, not a treatment. California Senate Office of Research.

MIND for better mental health, M. (2013). Mental health crisis care: Physical restraint in crisis - a report on physical restraint in hospital settings in England. UK.

Mohr, W. K., Mahon, M. M., \& Noone, M. J. (1998). A restraint on restraints: The need to reconsider the use of restrictive interventions. Archives of Psychiatric Nursing, 12(2), 95-106. doi: 10.1016/S0883-9417(98)80059-9

Moran, A., Cocoman, A., Scott, P. A., Mathews, A., Staniulene, V., \& Valimaki, M. (2009). Restraint and seclusion: a distressing treatment option? Journal of Psychiatric \& Mental Health Nursing, 16(7), 599-605. doi: 10.1111/j.13652850.2009.01419.x 
Moylan, L. B., \& Cullinan, M. (2011). Frequency of assault and severity of injury of psychiatric nurses in relation to the nurses' decision to restrain. Journal of Psychiatric and Mental Health Nursing, 18(6), 526-534. doi: 10.1111/j.13652850.2011.01699.x

Muralidharan, S., \& Fenton, M. (2012). Containment strategies for people with serious mental illness (Review).

National Institute for Health and Care Excellence, N. I. f. H. a. C. E. (2015). Violence and Aggression: Short-Term Management in Mental Health, Health and Community Settings. UK.

National Offenders Management Services, N. O. M. S. (2013). Minimising and managing physical restraint: Safeguarding processes, governance arrangements, and roles and responsibilities. UK.

Nelstrop, L., Chandler-Oatts, J., Bingley, W., Bleetman, T., Corr, F., Cronin-Davis, J., ... al., e. (2006). A systematic review of the safety and effectiveness of restraint and seclusion as interventions for the short-term management of violence in adult psychiatric inpatient settings and emergency departments. Worldviews on Evidence-Based Nursing, First Quarter, 8-18.

Paterson, B., \& Duxbury, J. (2007). Restraint and the question of validity. Nursing Ethics, 14(4), 535-545. doi: 10.1177/0969733007077888

Perkins, E., Prosser, H., Riley, D., \& Whittington, R. (2012). Physical restraint in a therapeutic setting; a necessary evil? International Journal of Law \& Psychiatry, 35(1), 43-49.

PPAO. (2000). Psychiatric Patient Advocate Office Review of Seclusion and Restraint Practices in Ontario Provinces in Ontario Provincial Psychiatric Hospital

Putkonen, A., Kuivalainen, S., O., L., E., R.-T., O.P., R., H., K., \& J., T. (2013). Clusterrandomized controlled trial of reducing seclusion and restraint in secured care of men with schizophrenia. Psychiatric Services, 64(9), 850-855.

Registered Nurses Association of Ontario, R. N. A. o. O. (2012). Promoting Safety: Alternative Approaches to the Use of Restraints. Ontario, Canada.

Riahi, S., Dawe, I., Hernandez, A., Klassen, P., \& Wasdell, M. (2014). Implementation of recovery rounds in the prevention of restraint and seclusion. In I. Needham, M. Kingma, K. McKenna, F. Odile, C. Tuttas, S. Kingma, \& N. Oud (Eds.), Violence in the Health Sector Towards Safety, Security and Well Being for all (pp. 125-131). Amsterdam: Kavanah Publishing.

Royal College of Nursing, R. C. o. N. (2008). Let's talk about restraint: Rights, risks and responsibilities. UK.

Ryan, C., \& Bowers, L. (2006). An analysis of nurses' post-incident manual restraint report. Journal of Psychiatric \& Mental Health Nursing, 13, 527-532.

Sailas, E., \& Fenton, M. (2009). Seclusion and restraints for people with serious mental illness (Review).

Sailas, E., \& Fenton, M. (2012). Seclusion and restraints for people with serious mental illness.

Sequeira, H., \& Halstead, S. (2004). The psychological effects on nursing staff of administering physical restraint in a secure psychiatric hospital: 'When I go home, it's then that I think about it. The British Journal of Forensic Practice, 6(1), 3-15. doi: 10.1108/14636646200400002 
Soininen, P., Välimäki, M., Noda, T., Puukka, P., Korkeila, J., Joffe, G., \& Putkonen, H. (2013). Secluded and restrained patients' perceptions of their treatment. International Journal of Mental Health Nursing, 22(1), 47-55. doi: 10.1111/j.1447-0349.2012.00838.x

Southcott, J., \& Howard, A. (2007). Effectiveness and safety of restraint and breakaway techniques in a psychiatric intensive care unit. Nursing Standard, 21(36), 35-41.

Stewart, D., Bowers, L., Simpson, A., Ryan, C., \& Tziggili, M. (2009). Mechanical Restraint of Adult Psychiatric Inpatients: A Literture Review (D. o. M. H. a. L. Disability, Trans.). London, England: City University.

Strout, T. D. (2010). Perspectives on the Experience of Being Physically Restrained: An Integrative Review of the Qualitative Literature. International Journal of Mental Health Nursing, 19, 416-427.

Stubbs, B., Leadbetter, D., Paterson, B., Yorston, G., Knight, C., \& Davis, S. (2009). Physical intervention: A review of the literature on its use, staff and patient views, and the impact of training. Journal of Psychiatric and Mental Health Nursing, 16(1), 99-105. doi: 10.1111/j.1365-2850.2008.01335.x

Terpstra, T. L., Terpstra, T.L., Pettee, E.J. \& Hunter, M. (2001). Nursing staff's attitude toward seclusions and restraint. Journal of Psychosocial Nursing \& Mental Health Services, 39(5), 20-28.

Walsh, D., \& Downe, S. (2006). Appraising the Quality of Qualitative Research. Midwifery, 22, 108-119.

Whittemore, R., \& Knafl, K. A. (2005). The Integrative Review: Updated Methodology Journal of Advanced Nursing, 52(5), 546-553. 
Table 1: Search Terms

\begin{tabular}{|c|c|c|c|}
\hline Population & D Intervention A & D Context & Outcome \\
\hline $\begin{array}{c}\text { mental health } \\
\text { OR } \\
\text { psychiatry } \\
\text { OR } \\
\text { mental disorder } \\
\text { OR } \\
\text { violence } \\
\text { OR } \\
\text { aggression } \\
\text { OR } \\
\text { self-injurious } \\
\text { behavior } \\
\text { OR } \\
\text { suicide } \\
\text { OR } \\
\text { suicide-attempt } \\
\text { OR } \\
\text { mentally ill } \\
\text { persons } \\
\text { OR } \\
\text { nursing } \\
\text { OR } \\
\text { psychiatric } \\
\text { nursing } \\
\text { OR } \\
\text { nurs* }\end{array}$ & $\begin{array}{c}\text { restraint } \\
\text { OR } \\
\text { physical intervention } \\
\text { OR } \\
\text { physical restraint } \\
\text { OR } \\
\text { coercive practice } \\
\text { OR } \\
\text { manual restraint } \\
\text { OR } \\
\text { clinical holding } \\
\text { OR } \\
\text { restrictive practice } \\
\text { OR } \\
\text { restraint hold } \\
\text { OR } \\
\text { physical control } \\
\text { OR } \\
\text { last resort } \\
\text { OR } \\
\text { behavior control } \\
\text { OR } \\
\text { coercion } \\
\text { OR } \\
\text { immobilization } \\
\text { OR } \\
\text { nursing care } \\
\text { OR } \\
\text { safety-management }\end{array}$ & $\begin{array}{c}\text { inpatient } \\
\text { OR } \\
\text { mental health } \\
\text { services } \\
\text { OR } \\
\text { psychiatric } \\
\text { hospitals } \\
\text { OR } \\
\text { psychiatric } \\
\text { department }\end{array}$ & $\begin{array}{c}\text { experience } \\
\text { OR } \\
\text { attitude } \\
\text { OR } \\
\text { perception } \\
\text { OR } \\
\text { decision-making } \\
\text { OR } \\
\text { nursing care } \\
\text { OR } \\
\text { safety management }\end{array}$ \\
\hline
\end{tabular}


Table 2: Integrative Review Inclusion \& Exclusion Criteria

\begin{tabular}{|c|c|c|}
\hline & Inclusion Criteria & Exclusion Criteria \\
\hline Population & $\begin{array}{l}\text { Mental health; psychiatric } \\
\text { nursing; adult psychiatry }\end{array}$ & $\begin{array}{l}\text { Non-mental health } \\
\text { population and setting; } \\
\text { non nursing professionals; } \\
\text { family perception of } \\
\text { restraint use; specialized } \\
\text { populations (geriatrics, } \\
\text { adolescent, intellectual } \\
\text { disability, forensic); } \\
\text { nursing students, patient } \\
\text { perception, staff training. }\end{array}$ \\
\hline Intervention & $\begin{array}{l}\text { Application of and or } \\
\text { witnessing of the } \\
\text { application of manual and } \\
\text { or mechanical restraint } \\
\text { (studies which included } \\
\text { mechanical and or manual } \\
\text { and seclusion were } \\
\text { included) }\end{array}$ & $\begin{array}{l}\text { Seclusion practices; } \\
\text { chemical restraint }\end{array}$ \\
\hline Type of study & $\begin{array}{l}\text { Qualitative and } \\
\text { Quantitative }\end{array}$ & $\begin{array}{l}\text { Thesis, policy documents, } \\
\text { book chapter, } \\
\text { commentaries, editorials, } \\
\text { literature reviews }\end{array}$ \\
\hline Language & English & Other languages \\
\hline
\end{tabular}

Table 3: Appraisal Grading

\begin{tabular}{|l|l|}
\hline \multicolumn{1}{|c|}{ Grade } & \multicolumn{1}{c|}{ Description } \\
\hline Grade A & No, or few flaws. The study validity, reliability and generalizability are high. \\
\hline Grade B & Some flaws, unlikely to affect the validity, reliability and generalizability of the study. \\
\hline Grade C & Some flaws that may affect the validity, reliability and generalizability of the study. \\
\hline Grade D & $\begin{array}{l}\text { Significant flaws that are very likely to affect the validity, reliability and generalizability } \\
\text { of the study. }\end{array}$ \\
\hline
\end{tabular}


Figure 1: Flow Diagram of Integrative Review

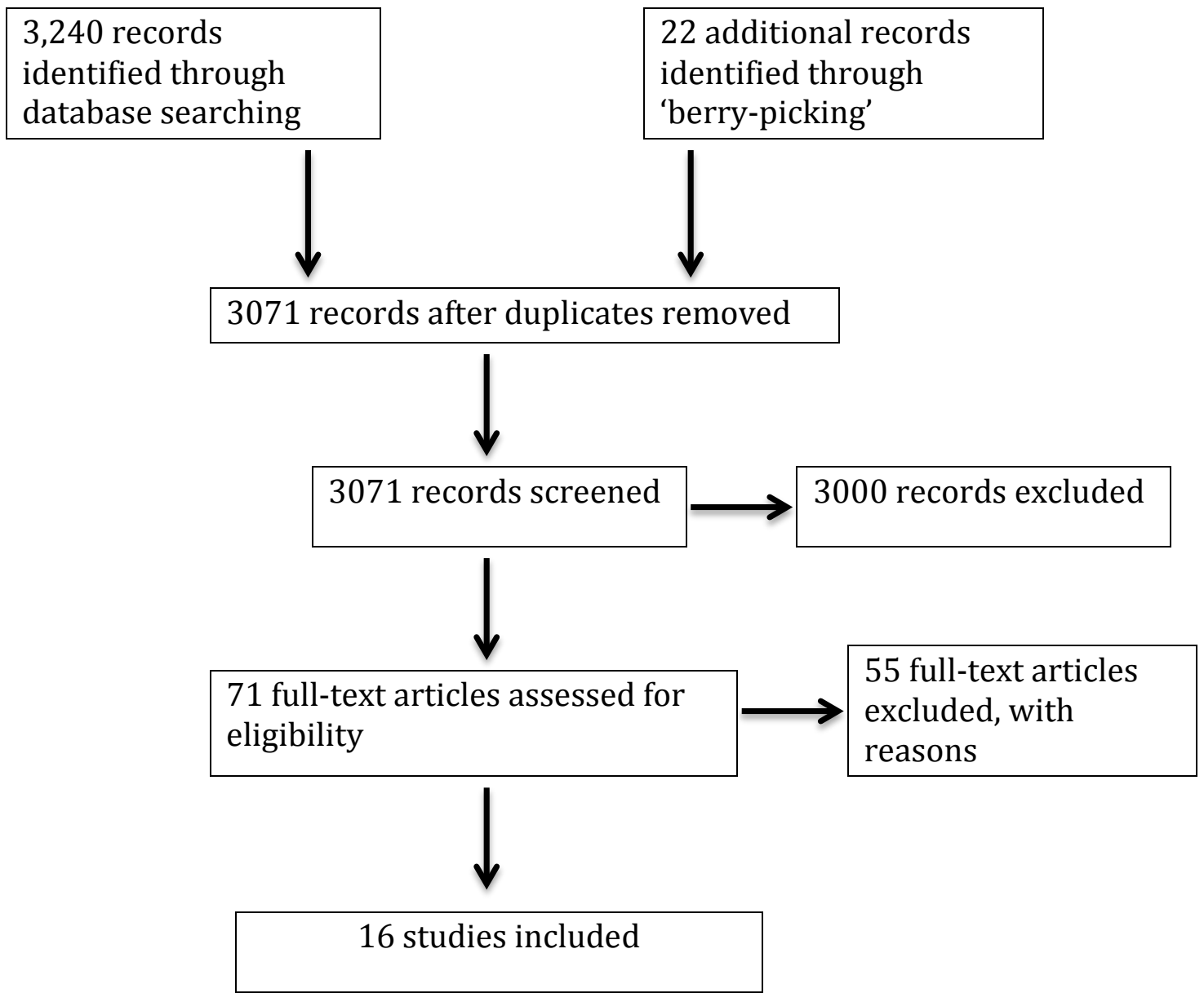


Table 4: Summary of Studies

\begin{tabular}{|c|c|c|c|c|c|}
\hline $\begin{array}{c}\text { Author } \\
\text { (year) }\end{array}$ & Aim & $\begin{array}{l}\frac{\text { Setting \& }}{\text { Participants }} \\
\text { Pricis }\end{array}$ & Methods & Key Themes & $\begin{array}{c}\text { Appraisal } \\
\text { Grading }\end{array}$ \\
\hline $\begin{array}{l}\text { Bigwood \& } \\
\text { Crowe } \\
(2008)\end{array}$ & $\begin{array}{l}\text { To understand the } \\
\text { mental health nurses' } \\
\text { experiences of } \\
\text { physical restraint. }\end{array}$ & $\begin{array}{l}\text { Acute adult } \\
\text { inpatient } \\
\text { psychiatry } \\
\underline{\text { UK) }} \\
\text { Seven nurses }\end{array}$ & $\begin{array}{l}\text { Descriptive } \\
\text { phenomenological }\end{array}$ & $\begin{array}{l}\text { 'Safety for all' } \\
\text { 'Restraint as a } \\
\text { Necessary } \\
\text { Intervention' } \\
\text { 'Role Conflict' } \\
\text { 'Maintaining Control' }\end{array}$ & Grade A \\
\hline $\begin{array}{l}\text { Bonner et al. } \\
(2002)\end{array}$ & $\begin{array}{l}\text { To establish the } \\
\text { feasibility of using } \\
\text { semi structured } \\
\text { interviews with } \\
\text { patients and staff in } \\
\text { the aftermath of } \\
\text { untoward incidents } \\
\text { involving physical } \\
\text { restraint. To gather } \\
\text { information on the } \\
\text { factors patients and } \\
\text { staff groups found } \\
\text { helpful and unhelpful, } \\
\text { during and in the } \\
\text { aftermath of }\end{array}$ & $\begin{array}{l}\text { Mental health } \\
\text { ward (UK) } \\
\text { Six incidents } \\
\text { were analyzed } \\
\text { and twelve } \\
\text { staff and six } \\
\text { patients were } \\
\text { interviewed. }\end{array}$ & $\begin{array}{l}\text { Qualitative semi } \\
\text { structured } \\
\text { interviews }\end{array}$ & $\begin{array}{l}\text { 'Restraint as a Last } \\
\text { Resort' } \\
\text { 'Role Conflict' } \\
\text { 'Psychological Impact' }\end{array}$ & Grade B \\
\hline
\end{tabular}




\begin{tabular}{|c|c|c|c|c|c|}
\hline $\begin{array}{c}\text { Author } \\
\text { (year) }\end{array}$ & Aim & $\begin{array}{c}\text { Setting \& } \\
\text { Participants }\end{array}$ & Methods & Key Themes & $\begin{array}{c}\text { Appraisal } \\
\text { Grading }\end{array}$ \\
\hline & $\begin{array}{l}\text { restraint. To explore } \\
\text { the lived subjective } \\
\text { experience of } \\
\text { restraint }\end{array}$ & & & & \\
\hline $\begin{array}{l}\text { Bowers et al. } \\
(2012)\end{array}$ & $\begin{array}{l}\text { To assess the } \\
\text { relationship of show } \\
\text { of force and manual } \\
\text { restraint to other } \\
\text { conflict behaviours, } \\
\text { the use of } \\
\text { containment } \\
\text { methods, service } \\
\text { environment, } \\
\text { physical } \\
\text { environment, patient } \\
\text { routines, staff } \\
\text { characteristics, and } \\
\text { staff group variables. }\end{array}$ & $\begin{array}{l}136 \text { acute } \\
\text { mental health } \\
\text { wards (UK) }\end{array}$ & $\begin{array}{l}\text { A multivariate, } \\
\text { cross-sectional } \\
\text { study }\end{array}$ & 'Staff Composition' & Grade $\mathrm{A}$ \\
\hline $\begin{array}{l}\text { Gelkopf et al. } \\
\text { (2009) }\end{array}$ & $\begin{array}{l}\text { To examin the } \\
\text { nurses' attitudes } \\
\text { regarding the goals of } \\
\text { restraint, the } \\
\text { environmental } \\
\text { conditions } \\
\text { influencing restraint, } \\
\text { the emotional aspects } \\
\text { of restraint, and their } \\
\text { beliefs about whether }\end{array}$ & $\begin{array}{l}\frac{350-\text { bed }}{\text { Mental Health }} \\
\underline{\text { Centre (Israel) }} \\
111 \text { nurses }\end{array}$ & $\begin{array}{l}\text { Quantitative - } \\
\text { surveys }\end{array}$ & $\begin{array}{l}\text { 'Nurses' Knowledge } \\
\text { and Perception of the } \\
\text { Patient' } \\
\text { 'Staff Composition' }\end{array}$ & Grade A \\
\hline
\end{tabular}




\begin{tabular}{|c|c|c|c|c|c|}
\hline $\begin{array}{c}\text { Author } \\
\text { (year) }\end{array}$ & Aim & $\begin{array}{c}\text { Setting \& } \\
\text { Participants }\end{array}$ & Methods & Key Themes & $\begin{array}{c}\text { Appraisal } \\
\text { Grading }\end{array}$ \\
\hline & $\begin{array}{l}\text { other staff members } \\
\text { should participate in } \\
\text { restraint procedures. }\end{array}$ & & & & \\
\hline $\begin{array}{l}\text { Holzworth \& } \\
\text { Wills (1999) }\end{array}$ & $\begin{array}{l}\text { To investigate the } \\
\text { clinical judgment of } \\
\text { psychiatric nurses } \\
\text { using judgment } \\
\text { analysis within the } \\
\text { framework of social } \\
\text { judgment theory. }\end{array}$ & $\begin{array}{l}\frac{\text { Short-term }}{\text { psychiatric }} \\
\text { care facility } \\
\underline{\text { (USA) }} \\
\text { Nine nurses }\end{array}$ & $\begin{array}{l}\text { Quantitative } \\
\text { questionnaire }\end{array}$ & $\begin{array}{l}\text { 'Restraint as a Last } \\
\text { Resort' } \\
\text { 'Nurses' Knowledge } \\
\text { and Perception of the } \\
\text { Patient' } \\
\text { 'Staff Composition' }\end{array}$ & Grade B \\
\hline $\begin{array}{l}\text { Kontio et al. } \\
(2010)\end{array}$ & $\begin{array}{l}\text { To explore the ethical } \\
\text { aspects of nurses' and } \\
\text { physicians' } \\
\text { perceptions of: 1) } \\
\text { what actually } \\
\text { happens when an } \\
\text { aggressive behavior } \\
\text { episode occurs on a } \\
\text { ward; and 2) what } \\
\text { alternatives to } \\
\text { seclusion and } \\
\text { restraint are in use as } \\
\text { normal standard } \\
\text { practice in acute } \\
\text { psychiatric care. }\end{array}$ & $\begin{array}{l}\frac{\text { Two }}{\text { psychiatric }} \\
\underline{\text { hospitals }} \\
\underline{(\text { Finland })} \\
22 \text { nurses and } \\
\text { Five } \\
\text { physicians }\end{array}$ & $\begin{array}{l}\text { Qualitative - focus } \\
\text { groups }\end{array}$ & 'Role Conflict' & Grade B \\
\hline $\begin{array}{l}\text { Lee et al. } \\
(2003)\end{array}$ & $\begin{array}{l}\text { To explore nurses' } \\
\text { views related to their } \\
\text { last experience of }\end{array}$ & $\begin{array}{l}\text { 63 randomly } \\
\text { selected } \\
\text { secure and }\end{array}$ & $\begin{array}{l}\text { Quantitative - } \\
\text { survey }\end{array}$ & $\begin{array}{l}\text { 'Maintaining Control' } \\
\text { 'Nurses' Knowledge } \\
\text { and Perception of the }\end{array}$ & Grade C \\
\hline
\end{tabular}




\begin{tabular}{|c|c|c|c|c|c|}
\hline $\begin{array}{c}\text { Author } \\
\text { (year) }\end{array}$ & Aim & $\begin{array}{c}\text { Setting \& } \\
\text { Participants }\end{array}$ & Methods & Key Themes & $\begin{array}{c}\text { Appraisal } \\
\text { Grading }\end{array}$ \\
\hline & $\begin{array}{l}\text { implementing } \\
\text { physical restraint. }\end{array}$ & $\begin{array}{l}\text { psychiatric } \\
\text { intensive care } \\
\text { units (UK) } \\
269 \text { nurses }\end{array}$ & & $\begin{array}{l}\text { Patient' } \\
\text { 'Staff Composition' }\end{array}$ & \\
\hline $\begin{array}{l}\text { Lemonidou } \\
\text { et al. (2002) }\end{array}$ & $\begin{array}{l}\text { To: a) investigate the } \\
\text { type of restriction } \\
\text { used to suppress } \\
\text { violent behavior of } \\
\text { psychiatric patients, } \\
\text { b) explore nurse's } \\
\text { attitudes toward } \\
\text { seclusion and } \\
\text { restraints, and c) } \\
\text { determine if there is } \\
\text { a difference in } \\
\text { nurse's attitudes due } \\
\text { to their level of } \\
\text { education and years } \\
\text { of experience. }\end{array}$ & $\begin{array}{l}\frac{12 \text { psychiatric }}{\text { wards }} \\
\text { (Greece) } \\
190 \text { nurses }\end{array}$ & $\begin{array}{l}\text { Quantitative - } \\
\text { survey }\end{array}$ & $\begin{array}{l}\text { 'Safety for all' } \\
\text { 'Maintaining Control' } \\
\text { 'Nurses' Knowledge } \\
\text { and Perception of the } \\
\text { Patient' } \\
\text { 'Staff Composition' }\end{array}$ & Grade B \\
\hline $\begin{array}{l}\text { Lindsey } \\
(2009)\end{array}$ & $\begin{array}{l}\text { To examine the } \\
\text { association of nurses' } \\
\text { work empowerment, } \\
\text { as well as, individual } \\
\text { characteristics of the } \\
\text { patient and of the } \\
\text { nurses with nurses' } \\
\text { decision to restrain. }\end{array}$ & $\begin{array}{l}\text { Four hospitals } \\
\text { (USA) } \\
\text { Thirty } \\
\text { psychiatric } \\
\text { nurses }\end{array}$ & $\begin{array}{l}\text { Correlational } \\
\text { descriptive design } \\
\text { Quantitative } \\
\text { questionnaires }\end{array}$ & $\begin{array}{l}\text { 'Restraint as a Last } \\
\text { Resort' } \\
\text { 'Maintaining Control' } \\
\text { 'Nurses' Knowledge } \\
\text { and Perception of the } \\
\text { Patient' } \\
\text { 'Staff Composition' }\end{array}$ & Grade A \\
\hline
\end{tabular}




\begin{tabular}{|c|c|c|c|c|c|}
\hline $\begin{array}{l}\text { Author } \\
\text { (year) }\end{array}$ & Aim & $\begin{array}{l}\text { Setting \& } \\
\text { Participants }\end{array}$ & Methods & Key Themes & $\begin{array}{c}\text { Appraisal } \\
\text { Grading }\end{array}$ \\
\hline & $\begin{array}{l}\text { The study also } \\
\text { examined the } \\
\text { decision patterns } \\
\text { used by psychiatric } \\
\text { nurses in response to } \\
\text { patient situations in } \\
\text { which restrain might } \\
\text { be considered. }\end{array}$ & & & & \\
\hline $\begin{array}{l}\text { Marangos- } \\
\text { Frost \& wells } \\
\text { (2000) }\end{array}$ & $\begin{array}{l}\text { To explore the } \\
\text { possible influence of } \\
\text { nurses' thoughts and } \\
\text { feelings on the } \\
\text { decision to restrain. }\end{array}$ & $\begin{array}{l}\frac{\text { Psychiatric }}{\text { inpatient unit }} \\
\text { (Canada) } \\
\text { Six nurses } \\
\end{array}$ & $\begin{array}{l}\text { Qualitative - } \\
\text { Ethnographic } \\
\text { design }\end{array}$ & $\begin{array}{l}\text { 'Restraint as a Last } \\
\text { Resort' } \\
\text { 'Role Conflict' }\end{array}$ & Grade B \\
\hline $\begin{array}{l}\text { McCain \& } \\
\text { Kornegay } \\
(2005)\end{array}$ & $\begin{array}{l}\text { Explore the lived } \\
\text { experiences of } \\
\text { psychiatric nurses' } \\
\text { use of physical } \\
\text { restraints as } \\
\text { perceived by } \\
\text { Registered Nurses } \\
\text { with } 5 \text { years or more } \\
\text { of psychiatric nursing } \\
\text { experience. }\end{array}$ & $\begin{array}{l}\frac{\text { Inpatient }}{\text { psychiatric }} \\
\text { unit (USA) } \\
\text { Nine nurses }\end{array}$ & $\begin{array}{l}\text { Qualitative - } \\
\text { Phenomenological } \\
\text { method }\end{array}$ & $\begin{array}{l}\text { 'Restraint as a } \\
\text { Necessary } \\
\text { Intervention' } \\
\text { 'Restraint as a Last } \\
\text { Resort' }\end{array}$ & Grade B \\
\hline $\begin{array}{l}\text { Moran et al. } \\
(2009)\end{array}$ & $\begin{array}{l}\text { To explore the } \\
\text { emotions and feelings } \\
\text { experienced by } \\
\text { nurses in response to } \\
\text { restraint and }\end{array}$ & $\begin{array}{l}\frac{\text { Psychiatric }}{\text { hospital }} \\
\underline{\text { (Ireland) }} \\
23 \text { nurses }\end{array}$ & $\begin{array}{l}\text { Qualitative - focus } \\
\text { groups }\end{array}$ & $\begin{array}{l}\text { 'Restraint as a Last } \\
\text { Resort' } \\
\text { 'Psychological Impact' }\end{array}$ & Grade A \\
\hline
\end{tabular}




\begin{tabular}{|c|c|c|c|c|c|}
\hline $\begin{array}{c}\text { Author } \\
\text { (year) }\end{array}$ & Aim & $\begin{array}{c}\text { Setting \& } \\
\text { Participants }\end{array}$ & Methods & Key Themes & $\begin{array}{c}\text { Appraisal } \\
\text { Grading }\end{array}$ \\
\hline & $\begin{array}{l}\text { seclusion } \\
\text { interventions. }\end{array}$ & & & & \\
\hline $\begin{array}{l}\text { Moylan \& } \\
\text { Cullinan } \\
\text { (2011) }\end{array}$ & $\begin{array}{l}\text { To examine assault } \\
\text { and injury in relation } \\
\text { to the nurse's } \\
\text { decision to restrain. }\end{array}$ & $\begin{array}{l}\text { Five } \\
\text { institutions - } \\
\underline{\text { two }} \\
\text { psychiatric } \\
\frac{\text { hospital, three }}{\text { with }} \\
\frac{\text { psychiatric }}{\text { units (USA) }} \\
110 \text { nurses }\end{array}$ & Mixed method & $\begin{array}{l}\text { 'Role Conflict' } \\
\text { 'Psychological Impact' }\end{array}$ & Grade B \\
\hline $\begin{array}{l}\text { Perkins et al. } \\
(2012)\end{array}$ & $\begin{array}{l}\text { To explore the } \\
\text { attitudes of staff } \\
\text { towards restraint and } \\
\text { understand some of } \\
\text { the influences on } \\
\text { their decision-making } \\
\text { and behavior. }\end{array}$ & $\begin{array}{l}\text { Acute adult } \\
\text { mental health } \\
\text { setting (UK) } \\
\text { Thirty nurses }\end{array}$ & $\begin{array}{l}\text { Retrospective } \\
\text { analysis - } \\
\text { interviews and } \\
\text { focus groups }\end{array}$ & $\begin{array}{l}\text { 'Restraint as a } \\
\text { Necessary } \\
\text { Intervention' } \\
\text { 'Maintaining Control' } \\
\text { 'Nurses' Knowledge } \\
\text { and Perception of the } \\
\text { Patient' }\end{array}$ & Grade B \\
\hline $\begin{array}{l}\text { Sequeira \& } \\
\text { Halstead } \\
(2004)\end{array}$ & $\begin{array}{l}\text { To explore the } \\
\text { psychological } \\
\text { responses of nursing } \\
\text { staff to restraint. }\end{array}$ & $\begin{array}{l}\text { Specialized } \\
\text { mental health } \\
\begin{array}{l}\text { care hospital } \\
(\mathrm{UK})\end{array} \\
\begin{array}{l}\text { Seventeen } \\
\text { nurses }\end{array}\end{array}$ & $\begin{array}{l}\text { Qualitative semi } \\
\text { structured } \\
\text { interviews }\end{array}$ & 'Psychological Impact' & Grade $A$ \\
\hline Terpstra et & To explore the & 376-bed & Quantitative & 'Safety for all' & Grade C \\
\hline
\end{tabular}




\begin{tabular}{|l|l|l|l|l|l|}
\hline $\begin{array}{c}\text { Author } \\
\text { (year) }\end{array}$ & \multicolumn{1}{|c|}{ Aim } & \multicolumn{1}{c|}{$\begin{array}{c}\text { Setting \& } \\
\text { Participants }\end{array}$} & \multicolumn{1}{c|}{ Methods } & \multicolumn{1}{c|}{ Key Themes } & \multicolumn{1}{c|}{$\begin{array}{c}\text { Appraisal } \\
\text { Grading }\end{array}$} \\
\hline al. (2001) & $\begin{array}{l}\text { attitudes and } \\
\text { opinions of nurses } \\
\text { toward seclusion and } \\
\text { restraint use. }\end{array}$ & $\begin{array}{l}\text { psychiatric } \\
\text { hospital (USA) }\end{array}$ & surveys & $\begin{array}{l}\text { 'Maintaining Control' } \\
\text { 'Nurses' Knowledge } \\
\text { and Perception of the } \\
\text { Patient' } \\
\text { 'Staff Composition' }\end{array}$ & \\
\hline
\end{tabular}




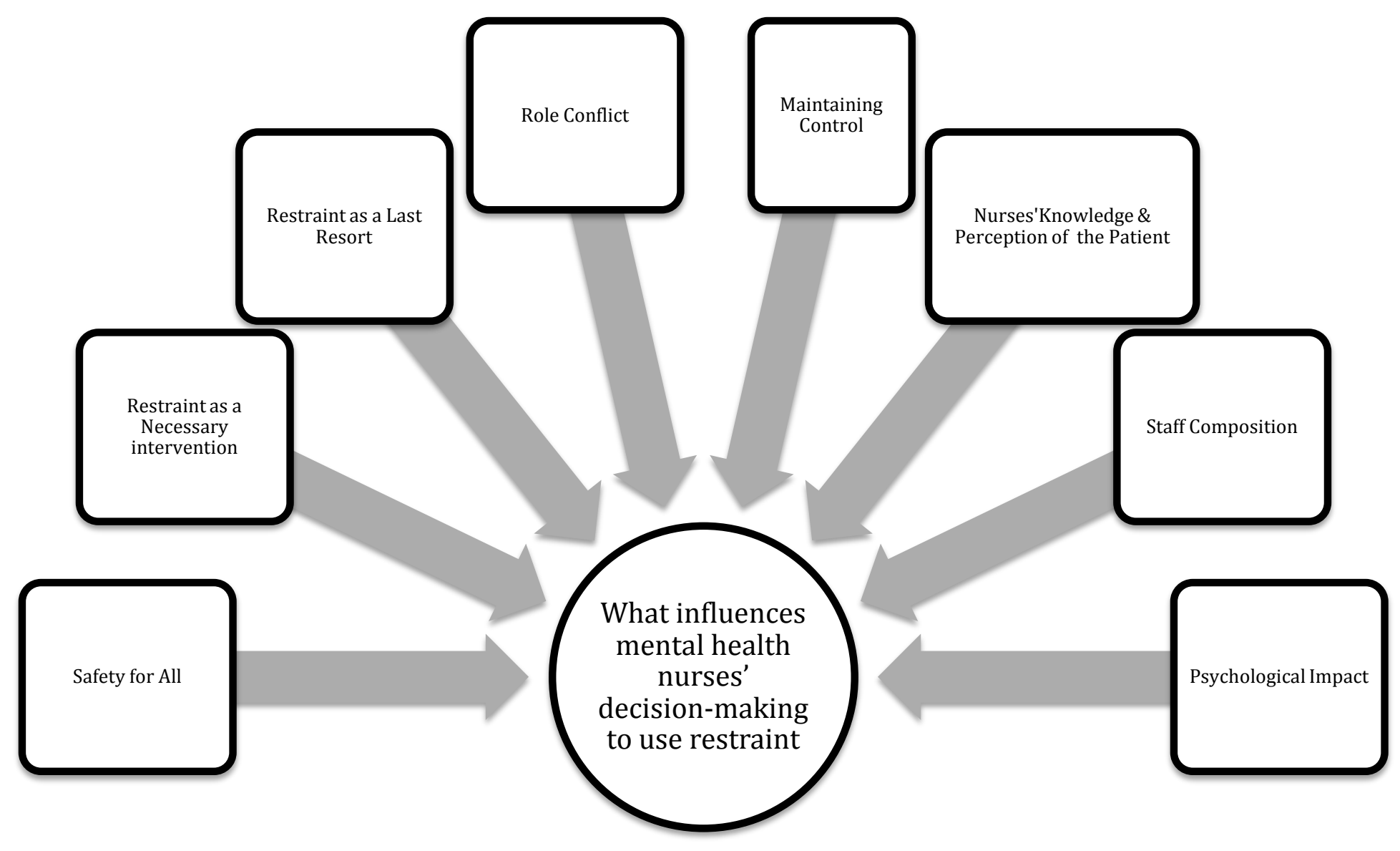

